\title{
DisABILITY CIVIL RightS AND A NEW \\ PARADIGM FOR THE TWENTY-FIRST CENTURY: THE EXPANSION OF CIVIL RIGHTS BEYOND RACE, GENDER, AND AGE
}

\author{
Paul Steven Miller $\uparrow$
}

\section{THE DEVELOPMENT OF CIVIL RIGHTS IN AMERICA}

The struggle for equal opportunity and civil rights is etched in America's collective consciousness. Images of fire hoses aimed at peaceful protesters, lunch counter demonstrations, and women marching in the streets helped move this nation away from policies of Jim Crow and gender inequity in the workplace. American law and public policy finally concluded that people of color, women, and other minorities should not be treated differently from the rest of society. The exclusion and outright segregation of African-Americans and other ethnic and religious minority groups in public accommodations and housing was seliminated. ${ }^{1}$ In the workplace people of color and women who were explicitly denied jobs and promotion opportunities began to be protected by antidiscrimination laws ${ }^{2}$

$\uparrow$ Commissioner, United States Equal Employment Opportunity Commission; B.A., University of Pennsylvania, 1983; J.D., Harvard Law School, 1986. The author would like to thank Justine Lisser for all of her enthusiasm, hard work, and invaluable research assistance on this article. This article was written by Mr. Miller in his private capacity. No official support or endorsement by the EEOC or any other agency of the U.S. government is intended or should be inferred.

1. See, e.g., Tillman v. Wheaton-Haven Recreation Ass'n, 410 U.S. 431 (1973) (holding that membership in a neighborhood swimming pool association may not be denied on the basis of race to persons otherwise qualified by virtue of their residence); Jones $\mathrm{v}$. Alfred H. Mayer Co., 392 U.S. 409 (1968) (barring all racial discrimination in sale or rental of property, whether public or private); United States v. Johnson, 390 U.S. 563 (1968) (refusing service in a restaurant on the basis of race is not permitted); Heart of Atlanta Motel, Inc. v. United States, 379 U.S. 241 (1964) (stating that the Civil Rights Act of 1964 bars denial of motel accommodations to African-Americans); Katzenbach v. McClung, 379 U.S. 294 (1964) (holding the Civil Rights Act of 1964 barring segregation in restaurants constitutional); Bailey v. Patterson, 369 U.S. 31 (1962) (holding that no state may require racial segregation in interstate or intrastate bus transportation facilities).

2. See Civil Rights Act of 1964, as amended, 42 U.S.C. $\$ \$ 1981-2000$ (1994). See 
which forbade reservation of better jobs for white men. ${ }^{3}$ Older workers gained protection from discriminatory layoffs based solely on their age. ${ }^{4}$ Courts even began to grapple with the subtle ways employers found to discriminate. ${ }^{5}$ The purpose of the civil rights laws and regulations which were enacted seemed clear and straightforward-members of racial minority and religious groups, women, and older workers must be treated equally in all aspects of American society.

The government's response to discrimination grew out of the theoretically simple mandate that everyone should be treated equally and that differential treatment of individuals on the basis of race, gender, religion, or age was impermissible under the law. Barriers having a disparate impact on protected groups became impermissible. ${ }^{6}$ Equal

generally Albemarle Paper Co. v. Moody, 422 U.S. 405 (1975) (ruling on a lawsuit filed by black employees who complained of being locked into lower paying jobs after a new collective bargaining agreement merely tacked the previously "Negro" jobs and lines of progression onto the bottom of the formerly "white" jobs); Pettway v. American Cast Iron Pipe Co., 494 F.2d 211, 218-19 (5th Cir. 1974) (stating that explicitly segregated lines of progression were perpetuated by allegedly neutral selection criteria). In the area of women's rights, Title VII of the Civil Rights Act of 1964 preceded the Equal Pay Act, 29 U.S.C. 206(d) by one year. The Equal Pay Act amended the Fair Labor Standards Act to mandate equal pay for men and women doing jobs of "equal skill, effort, and responsibility ... which are performed under similar working conditions . . ." 29 U.S.C. \$ 206(d)(1) (1994). While an important tool, this act was not a comprehensive answer to the problems of discrimination faced by women because the job market was rigidly segregated by sex, thus limiting the number of jobs held by women which could be compared to those of men. Title VII was used to strike down so-called state protective laws which limited the hours and jobs women could work. See, e.g., Homemakers, Inc. v. Division of Indus. Welfare, 509 F.2d 20 (9th Cir. 1974) (striking down state protective statutes as creating impermissible distinctions based on sex), cert. denied, 423 U.S. 1063 (1976).

3. See International Bhd. of Teamsters v. United States, 431 U.S. 324 (1977) (holding that the trucking industry's and Teamsters' practices of reserving the more lucrative "overthe-road" driver jobs for whites, while relegating blacks to the lower-paying "local" driver slots, and manipulating the seniority system in such a way that any minority group members who attempted to switch positions after the over-the-road jobs technically became "open" would lose all previously earned seniority, perpetuated past discrimination and was not required by business necessity); Rodriguez v. East Tex. Motor Freight, 505 F.2d 40 (5th Cir. 1974) (describing similar employment practices as those in Teamsters, directed towards Mexican-Americans), vacated on other grounds, 431 U.S. 395 (1977).

4. A few years after the passage of Title VII, Congress amended the Fair Labor Standards Act to cover discrimination against persons over the age of 40 . See Age Discrimination in Employment Act of 1967 ("ADEA"), as amended, 29 U.S.C. \$§ 621-634 (1994).

5. See Griggs v. Duke Power Co., 401 U.S. 424 (1971) (recognizing the "disparate impact" theory of discrimination, under which neutral employment practices which adversely affected protected groups were prohibited unless they could be justified by business necessity).

6. The disparate impact analysis has been used generally to demonstrate discrimination arising from, inter alia, "standard" employment tests, such as intelligence tests, which disproportionately affect African-Americans. See, e.g., Albemarle Paper Co. v. 
treatment and the resulting "level playing field" would ensure that merit, not impermissible factors would govern employment decisions. The traditional model of antidiscrimination jurisprudence holds that all people must be treated exactly the same, regardless of race, gender, national origin, religion, or age. ${ }^{\text {? }}$

The early civil rights legislation, while expanded from the initial focus on race, still ignored people with disabilities. Disabled individuals' access to job opportunities and public accommodations was severely constricted, and they suffered from destructive stereotypes about their alleged inabilities to do many jobs. ${ }^{8}$ Discrimination against people with disabilities finally began to be addressed with the passage of the Rehabilitation Act of 1973, although that law only covered discrimination by federal entities or recipients of federal funds. ${ }^{9}$ Comprehensive legislation barring discrimination in private employment was not enacted until the landmark Americans with Disabilities Act of 1990 (the "ADA"). ${ }^{10}$ The ADA not only banned discrimination in employment, ${ }^{11}$ but also banned discrimination from most other facets of public life, including public accommodations operated by private entities, ${ }^{12}$ state and local government

Moody, 422 U.S. 405, 425 (1975) (applying disparate impact analysis to strength and agility tests which have an adverse impact on women). Cf. Berkman v. City of New York, $536 \mathrm{~F}$. Supp. 177 (E.D.N.Y. 1982), aff'd, 705 F.2d 584 (2d Cir. 1983).

7. An exception to this theory, although very much a part of the traditional methods used to combat discrimination, is affirmative action. While it is not the purpose of this article to give an in-depth history or analysis of affirmative action in the context of workplace discrimination, the original goals of affirmative action were rooted in the belief that historic inequities of access to education, experience, and opportunity made special efforts to bring previously-overlooked classes of people into the mainstream of economic life necessary. Thus, affirmative action was originally developed in order to "level the playing field," so that historically-excluded groups could compete on an equal basis in an atmosphere of equal treatment.

8. According to the census data, $82.1 \%$ of all Americans between the ages of twentyone and sixty-four are employed, compared with $76.9 \%$ of all persons identified as having a "non-severe disability" and $26.1 \%$ of all persons with a "severe" disability. NATIONAL INSTITUTE ON DISABILITY \& REHABILITATION, CHARTBOOK ON WORK AND DISABILITY IN THE UntTEd States (1998); see also Peter DAVID BlanCK, THE AMERICANS WITH Disabilities Act AND THE EMERging Work ForCE: EMployment of People with Mental RETARDATION 5 (1998); President's Committee on the Employment of People with Disabilities, Key Facts (visited Sept. 15, 1998) <http://www.pcepd.gov/pubs/fact/keyfacts. $\mathrm{htm}>$. People with disabilities comprise the largest percentage of people living in poverty. See Robert L. Burgdorf, Jr., The Americans with Disabilities Act: Analysis and Implications of a Second-Generation Civil Rights Statute, 26 HARV. C.R.-C.L. L. REv. 413, 422 (1991) (stating that the rate of poverty among people with disabilities is more than twice that of all other Americans).

9. See Rehabilitation Act of 1973, as amended, 29 U.S.C. $\S \$ 701-797$ (1994).

10. See Title I of the Americans with Disabilities Act of 1990 ("ADA"), 42 U.S.C. $\$ \$$ 12101-12213 (1994).

11. See id. \$§ 12111-12117.

12. See id. $\S \S 12181-12189$. 
services, ${ }^{13}$ transportation, ${ }^{14}$ and telecommunications. ${ }^{15}$

Nevertheless, the traditional civil rights model of treating people "exactly the same" does not apply to disability discrimination. For disabled people who need reasonable accommodations in order to perform the essential functions of their jobs, "equal" treatment is tantamount to a barrier to employment, not a gateway. ${ }^{16}$ A new paradigm for disability civil rights needed to be constructed. By virtue of the ADA's requirement to provide reasonable accommodations to qualified individuals with disabilities, employers must treat disabled employees differently in order to provide equal access to employment. This new paradigm of civil rights recasts the notion of a "level" playing field into one of an "accessible" playing field. In light of this difference, I will explore two interlocking questions. First, how has the dialogue concerning workplace civil rights changed in the context of the expansion of civil rights protections beyond race, gender, and age? Second, what are the implications of this change for civil rights enforcement and the workplace of the twenty-first century?

The disability rights paradigm is embodied in the ADA's mandate of an individualized approach as to who is covered by the antidiscrimination statute-that reasonable accommodations must be crafted to serve the specific needs of the disabled person and the requirements of the particular job, and that an interactive process between the employer and employee is required to arrive at the appropriate accommodation. This paradigm has positive lessons for the future. The disability rights paradigm provides a lens through which we can better manage the more complex and diverse workplace of the twenty-first century.

13. See id. $\$ \S 12131-12165$.

14. See id. $\$ \S 12141-12150$.

15. Title IV of the ADA, amending the Communications Act of 1934,47 U.S.C. $\$ \S$ 151-613 (1994), provides for greater accessibility of telecommunications devices. See id. $\S \S 401-613$; see also Telecommunications Act of 1996, Pub. L. No. 104-104, $\$ 255,110$ Stat. 56 (1996).

16. Title I of the ADA requires an employer to provide reasonable accommodation to qualified individuals with disabilities who are employees or applicants for employment. See 42 U.S.C. \$ 12112(b)(5) (1994). "In general, an accommodation is any change in the work environment or in the way things are customarily done that enables an individual with a disability to enjoy equal employment opportunities." 29 C.F.R. $\$ 1630.2(0)$ (1997). See generally 29 C.F.R. \$ 1630.9 (1998); Regulations to Implement the Equal Employment Provisions of the Americans with Disabilities Act, 29 C.F.R. pt. 1630, app. $\$ 1630.2(0)$ (1998). An employer's duty to provide a reasonable accommodation is limited only by whether it creates an undue hardship for the employer, that is, whether it causes significant difficulty or expense. Undue hardship analysis focuses on the resources and circumstances of the particular employer in relationship to the cost or difficulty of providing a specific accommodation. See 42 U.S.C. $\$ 12111(10)$ (1994); 42 U.S.C. $\$ 12112$ (b)(5)(A) (1994). 


\section{THE TRADITIONAL CIVIL RIGHTS PARADIGM}

The development of early civil rights enforcement evolved out of obvious and unambiguous patterns of exclusion existing in society. Specific statutes, legally enforceable covenants, and/or customs excluded African-Americans and many other groups from access to and inclusion in public accommodations and housing. ${ }^{17}$ Explicit race-based lines of progression, the outright exclusion of women from certain jobs, and de facto limitation of jobs to certain ethnic groups, races, and religions, created racially-, ethnically-, and gender-stratified employment patterns in the workplace. ${ }^{18}$ This discrimination was often rooted in racism, sexism, overt bigotry, or stereotypes about the abilities of certain persons due to race, national origin, gender, religion, or age.

The response to these acts of discrimination was theoretically simple-mandate equal treatment and remove barriers that have a disparate impact on protected groups. The "level playing field" resulting from the removal of bigotry and stereotyping would ensure that merit, not impermissible factors, governed employment decisions. The law, embodied primarily in the Civil Rights Act of 1964 (the "Civil Rights Act") ${ }^{19}$ requires that all workers be treated without regard to race, gender, national origin, and religion. Later, federal law prohibited discrimination on the basis of age. ${ }^{20}$ This premise of equal treatment was the basis for the evolution of disparate treatment and disparate impact.

Thus, from the early days of the Supreme Court's interpretation of Title VII, the Court made it clear that the objective of Title VII "was to achieve equality of employment opportunities and remove barriers that have operated in the past to favor an identifiable group of white employees over other employees."21 Further, the Court of Appeals for the Fifth Circuit held that, "one of Congress' main goals [in enacting Title VI] was to provide equal access to the job market for both men and women."22

Given the legacy of racism, sexism, and exclusion which exists in society and in the workplace, the traditional model of civil rights also eagerly embraced a broad concept of affirmative action as an additional

17. See cases cited supra note 1.

18. See sources cited supra note 2.

19. See 42 U.S.C. $\$ \$ 1981-2000$ (1994).

20. See 29 U.S.C. $\$ \$ 621-634$ (1994).

21. Griggs v. Duke Power Co., 401 U.S. 424, 429-30 (1971); accord McDonnell Douglas Corp. v. Green, 411 U.S. 792, 800 (1973); see also Alexander v. Gardner-Denver Co., 415 U.S. 36, 44 (1974) ("Congress enacted Title VII ... to assure equality of employment opportunities by eliminating those practices and devices that discriminate on the basis of race, color, religion, sex, or national origin.").

22. Diaz v. Pan Am. World Airways, 442 F.2d 385, 386 (5th Cir. 1971) (citing Weeks v. Southem Bell Tel. \& Tel. Co., 408 F.2d 228, 235 (5th Cir. 1969)). 
means of leveling the playing field. Following the passage of the Civil Rights Act, the underlying vision of equal treatment embodied in the traditional civil rights paradigm began to chip away at the gross inequities in the workplace. ${ }^{23}$

\section{THE DISABILITY CIVIL RIGHTS PARADIGM}

The disability civil rights paradigm is distinguished from the traditional civil rights approach by the individualized and contextual analysis required by the $\mathrm{ADA}{ }^{24}$ Title $\mathrm{I}$ of the $\mathrm{ADA}$ protects private sector employees from discrimination on the basis of disability. ${ }^{25}$ Rather than explicitly identifying particular conditions covered by the law, or specifying a list of covered disabilities for protection, the ADA contains broad language prohibiting discrimination against a "qualified individual with a disability" in hiring, promotion, discharge, compensation, and other terms and conditions of employment. ${ }^{26}$ An individual with a disability is defined by the ADA as a person with one or more physical or mental impairments that substantially limit him or her in performing a major life activity, a person with a record of such an impairment, or a person who is regarded as having such an impairment. ${ }^{27}$ An employer must make reasonable accommodations for qualified individuals with disabilities if such accommodations do not impose an undue hardship on the employer. ${ }^{28}$ Membership in the ADA protected class depends on the circumstances of the individual impairment and the ability to perform the essential functions of a given job, rather than immutable characteristics such as race, national origin, gender, or age.

Congress refused to list, classify, or quantify disabilities. Unlike the Social Security Administration's definition of disability for purposes of receiving disability payments, there is no list of impairments which

23. In the late 1960 s and 1970 s, the workplaces that activists sought to change were themselves remarkably static compared to the workplaces of today: workers tended to be employed by fewer employers over the course of their working careers, employees tended to remain with one employer longer, and work was usually performed at one or another defined "establishments" (depending on the type of job). "Telecommuting," "flex time," and a "permanent" contingent workforce were almost unheard of in most industries during this time.

24. Some have attacked the ADA for exactly these reasons. See Paul Steven Miller, The EEOC's Enforcement of the Americans with Disabilities Act in the Sixth Circuit, 48 CASE W. RES. L. REV. 217, 224-227 (1998). It appears that there is uneasiness in moving away from the traditional model of similar treatment for groups to a more individualized approach.

25. See 42 U.S.C. $\$ 12112(b)(5)$ (1994).

26. Id. § 12112(a) (1994).

27. See id. $\$ 12102(2)$.

28. See id.; see also sources cited supra note 16. 
automatically qualifies an individual for coverage under the $\mathrm{ADA}^{29}$ Moreover, courts have rejected designating any impairments as per se disabilities for purposes of the ADA. ${ }^{30}$ Thus, the first question in any case brought under the ADA is whether the claimant is a person with a disability. ${ }^{31}$ There is no such similar threshold question regarding coverage with a traditional Title VII analysis. ${ }^{32}$

Because every impairment is unique, even individuals with the same impairment may not be covered equally by the ADA. The same type of impairment may manifest itself differently in different individuals, thus substantially limiting a major life activity for one person, but not another. ${ }^{33}$ In addition, persons with identical impairments might be considered qualified for one job, but not for another, as the essential functions of the two jobs could vary significantly. ${ }^{34}$ One court offered the following hypothetical situation:

One hearing-impaired employee is an assembly worker who suffers no job limitations as a result of her hearing-impairment

29. See 42 U.S.C. $\$ 423$ (d)(1) (1994); 20 C.F.R. § 404.1505 (1996). See generally EEOC Enforcement Guidance on the Effect of Representations Made in Applications for Benefits on the Determination of Whether a Person Is a "Qualified Individual with a Disability" Under the Americans with Disabilities Act of 1990 (visited Nov. 30, 1998), available in <http://www.eeoc.gov/publicat.html .

30. See Bragdon v. Abbott, — U.S. - (1998), 118 S. Ct. 2196, 2202 (1998) ("In issuing these regulations [interpreting the Rehabilitation Act of 1973], HEW decided against including a list of disorders constituting physical or mental impairments, out of concern that any specific enumeration might not be comprehensive."); see also McKey v. Occidental Chem. Corp., 956 F. Supp. 1313, 1317 (S.D. Tex. 1997).

31. But see infra note 34 and accompanying text.

32. Discrimination on the basis of religion may be considered by some to raise a threshold coverage question. However, the burden of proving membership in a given religion and/or the existence of a sincerely held religious belief does not entail much scrutiny, nor is it a difficult burden to overcome. See, e.g., 29 C.F.R. $\$ 1605.1$ (1998) ("In most cases whether or not a practice or belief is religious is not at issue.").

33. In testimony before the House Committee on Education and Labor during the hearings on the then-proposed ADA, then EEOC Chairman Evan Kemp, Jr., in discussing the individualized analysis that employers will have to undergo with the ADA, stated:

I think the one thing that [the ADA] does is it asks employers to look at the disabled person as an individual, look at his strengths and his weaknesses, and look at the job that the employer wants filled and see if that person can fill the job .... I can be qualified for a job with one company and not qualified for a job with another company, even though it's the same job. Under Title VII, that wouldn't occur. If I were qualified for one job, generally I would be qualified for the same job in different corporations.

Staff of H.R. ReP. Comm. ON Educ. \& Lab., 101ST Cong., 2D Sess., Legislative History OF PUB. L. No. 101-336 (Comm. Print 1990).

34. See Taylor v. Principal Fin. Group, Inc., 93 F.3d 155 (5th Cir. 1996), cert. denied, - U.S. -, 117 S. Ct. 586 (1997), in which the court offered the above quoted hypothetical situation. 
disability; she is able to perform the essential functions of her job without accommodation. The other hearing-impaired employee, however, is a telephone operator who, because of her inability to hear, is limited in her ability to perform the essential functions of her job; this disabled employee may require a reasonable accommodation as a result of her impairment. Both employees are disabled, but only one employee is limited by her disability. ${ }^{35}$

Thus, much of the litigation that has taken place under the ADA involves the threshold question of whether the plaintiff is a covered individual with a disability for purposes of the ADA. ${ }^{36}$

Another difference between employment discrimination based upon disability and the traditional paradigm is that disability discrimination analysis requires a case-by-case inquiry. The reasonable accommodation requirement of the $\mathrm{ADA}$ is contextual and depends entirely upon the particular impairments of the person with the disability, the essential functions of the individual job at issue, and the cost of the needed accommodation. The ADA requires that an interactive process take place between the employer and the employee in arriving at the appropriate accommodation. ${ }^{37}$ An employer must assess, on an individual basis, not only whether the disabled person is covered by the $\mathrm{ADA}$, but also whether

35. Id. at 164 .

36. Some commentators have noted that the underlying purpose of the ADA is being undermined because federal courts have been dismissing large numbers of ADA cases at the summary judgment stage based upon findings that the individual plaintiff does not have a "disability" within the meaning of the ADA. This is true even in cases where individuals have serious impairments. See generally ThOMAs D'Agostino, NATIONAL DISABILITY LAW REPORTER-SPECIAL REPORT NO. 3, DEFINING "DISABILITY" UNDER THE ADA: 1997 Update ii (1997); Melinda Maloney \& Thomas D' Agostino, National DisabiLity Law REPORTER-SPECIAL REPORT No. 2, DEFINING "DISABILITY" UNDER THE ADA: AN ANALYSIS OF 60 DECISIONS 3, 7 (1996) (noting that while the substantial limitation requirement of the definition is intended to weed out claims made by individuals with relatively trivial impairments, the requirement is being applied by courts in a manner that excludes the claims of individuals with relatively severe physical and mental impairments). James G. Frierson, Heads You Lose, Tails You Lose: A Disturbing Judicial Trend in Defining Disability, 48 LAB. L.J. 419 (July 1997); Steven S. Locke, The Incredible Shrinking Protected Class: Redefining the Scope of Disability Under the Americans with Disabilities Act, 68 U. CoLo. L. REv. 107 (1997). A recent report issued by the National Disability Law Reporter found that courts held the plaintiff's impairment to be a "disability" in less than six percent of cases from 1995 and 1996 in which the plaintiff's disability status was at issue. See generally Study Finds Employers Win Most ADA Title I Judicial and Administrative Complaints, 22 MENT. \& PHYS. DIS. L. REP. 403 (May-June 1998).

37. See 29 C.F.R. \$ 1630.2(o)(3) (1998); see also Deane v. Pocono Med. Ctr., 142 F.3d 138,149 (3d Cir. 1998) (" [A]n employer who fails to engage in the interactive process runs a serious risk that it will erroneously overlook an opportunity to accommodate a statutorily disabled employee, and thereby violate the ADA.") (citing Mengine v. Runyon, 114 F.3d 415, 420-21 (3d Cir. 1997) (Rehabilitation Act of 1973 case)); Beck v. University of Wis., 75 F.3d 1130, 1135 (7th Cir. 1996). 
there is an accommodation that would enable that person to perform the essential functions of the job and whether the particular accommodation would cause an undue hardship. Thus, nothing could be farther from the traditional civil rights model which holds that equality ensues when everyone is treated exactly the same. ${ }^{38}$

Under the ADA, an individualized analysis is required to determine the type and appropriateness of an accommodation. An accommodation must be effective for the individual with a disability in his or her particular situation. $^{39}$ It needs to enable the individual to perform the essential functions of the position and should permit an applicant with a disability to have an equal opportunity to participate in the application process and to be considered for a job. Finally, a reasonable accommodation should allow the employee with a disability an equal opportunity to enjoy the benefits and privileges of employment that employees without disabilities enjoy. Thus, the term "reasonable accommodation" is a term of art that Congress defined only through examples of changes or modifications to be made or items to be provided to a qualified individual with a disability. The statutory definition of "reasonable accommodation" does not include any quantitative, financial, or other limitation regarding the extent of the obligations to make changes to a job or work environment. The only limitation on an employer's obligation to provide reasonable accommodation is that no such change or modification is required if it would cause "undue hardship" to the employer. ${ }^{40}$

For example, there is no standard reasonable accommodation for a person with a vision disorder, as the needs of each individual may vary along with the resources of the employer and the essential functions of the job. ${ }^{41}$ A person with low vision applying for a job as a telemarketer for a

38. Even in the context of disparate impact and affirmative action, victims of discrimination are still viewed as members of statistical groups, where the group had to be treated equally. Thus, a selection test would be found to have an adverse impact on AfricanAmericans generally, without allowances for individual variations in test score, or a minimum height requirement would likewise be found to discriminate against women in the aggregate. Similarly, affirmative action was directed at all members of a given group, not applied on a particularized or individual basis.

39. See 29 C.F.R. $\$ 1630.9$ (1998); see also Bryant v. Better Bus. Bureau of Md., 923 F. Supp. 720 (D. Md. 1996); Davis v. York Int'l, Inc., No. CIV.A.92-3545, 1993 WL 524761 , at $* 1$ (Md. Nov. 22, 1993); H.R. REP. No. 101-485, pt. 2, at 66 (1990) ("A reasonable accommodation should be effective for the employee."); S. REP. No. 101-116, at 35 (1989) (reasonableness of an accommodation is assessed "in terms of effectiveness and equal opportunity").

40. See 42 U.S.C. \$ 12112 (b)(5)(A) (1994).

41. The first test of any accommodation, of course, is whether the accommodation would be effective, i.e., whether it would allow an otherwise qualified person to perform the essential functions of the job at issue. See Evans v. Federal Express Corp., 133 F.3d 137, 140 (1st Cir. 1998) ("One element in the reasonableness [of an accommodation] is likelihood of success."); see also Bryant, 923 F. Supp. at 720. 
small company might need just to have the product information sheet printed out in large font size in order to perform the essential functions of that job. A reasonable accommodation for another person with similar low vision applying for a writer/editor job at a large publisher might need to be provided with an optical scanner and talking computer. Congress refused to set a monetary requirement or threshold limit for providing reasonable accommodations. Thus, the determination of whether an accommodation creates an undue hardship depends upon the individual circumstances of each employer. Clearly, an accommodation that might be considered a hardship for "Joe's Corner Garage" might not be a hardship for General Motors.

This individualized, person-by-person approach of the ADA is a departure from the traditional civil rights approach embodied in Title VII, which lays down broad and general rules that apply to all employees and employers across the board. The individualized treatment mandated by the ADA means that employers must exercise judgment in determining how to respond to a particular applicant or employee.

Finally, in contrast to the traditional civil rights paradigm, the nature of disability discrimination is more intensely personal as opposed to groupdirected. People with disabilities are generally not perceived as being members of a group that a particular employer dislikes or discriminates against. ${ }^{42}$ While there may be some employers who have a specific animus towards disabled people, such malevolence is more visible against people of color in the form of racism or against women in the form of sexism. Malevolence is not often the prime motivation for excluding people with disabilities from the workplace. ${ }^{43}$ Rather, pity towards, discomfort with, and fear of people with disabilities are more likely to shape the stereotypes. ${ }^{44}$ Employers are more likely to feel that people with

42. An exception may be with respect to people with psychiatric disabilities. For example, it is ironic that the highest incidence of disability is psychiatric, and yet psychiatric disability promotes the greatest prejudice. The National Institute of Mental Health estimated that there are over three million adults age 18-69 who have a serious mental illness, of whom $70-90 \%$ are unemployed. In a poll done by Lou Harris, $47 \%$ of those surveyed were very comfortable with people who are blind, and $59 \%$ of those surveyed were very comfortable with people who use a wheelchair, while only $19 \%$ of the people surveyed were very comfortable with people with mental illness. See National Organization on Disability, Public Attitudes Toward People with Disabilities (survey conducted by Louis Harris and Associates, Inc. 1991).

43. See Alexander v. Choate, 469 U.S. 287, 295 (1985) (reasoning that discrimination against people with disabilities is "most often the product, not of invidious animus," but rather of thoughtless and indifferent attitudes).

44. See, e.g., Jacobus tenBroek \& Floyd W. Matson, The Disabled and the Law of Welfare, 54 CAL. L. REv. 809, 816 (1966) (discussing the older "custodial" attitude towards people with disabilities "typically expressed in policies of segregation and shelter, of special treatment and separate institutions") quoted in ROBERT J. BURGDORF, JR., DISABILITY 
disabilities are simply helpless, flawed, or unable to function independently in the workplace due to their disability. ${ }^{45}$

A stumbling block to society's acceptance of the ADA is that civil rights laws have generally applied to groups of people who were thought of as sharing common characteristics and experiences. Society does not think of people with disabilities as part of a singular, unified group. Employers see little similarity among people with different types of disabilities. For example, blind people are thought to have little in common with paraplegics. By contrast, race, gender, and religion all have a cultural component which identifies and unifies the group. ${ }^{46}$ As the perception remains that disability is an individual flaw, employers are less likely to recognize that their actions are affected by negative stereotypes. Therefore, while Stephen Hawking, the physicist who uses a wheelchair and other assistive devices, or Tony Coelho, the former U.S. Congressman who has epilepsy, may be accepted in the workplace, employers may still have stereotypes about deaf people or people with mental illness which lead to discrimination in that same workplace.

Moreover, many people with disabilities do not think of themselves as sharing characteristics or experiences with others differently disabled from themselves. Many people with disabilities suffer from the same sense of fragmentation that employers have. The individual nature of inclusion in the protected class, the contextual analysis required by the $\mathrm{ADA}$, and the lack of homogeneity among people with disabilities indicate a civil rights paradigm different from the traditional model.

\section{THE IMPLICATIONS OF A NEW CIVIL RIGHTS PARADIGM FOR THE TWENTY-FIRST CENTURY}

The workplace has changed over the past thirty years since the Civil Rights Act was passed.

In the last five years, almost everything about working in America has changed. The places Americans work, the way they work, the relationship they have with their boss and peers, the security of their jobs-all of these things and many, many more have changed. We have experienced a workplace revolution....

DisCRIMINATION IN EMPLOYMENT LAW (1995). See generally JosePH P. SHAPIRO, No PITY, PEOPLE WITH DisABILITIES FoRgING A NEW CIVIL Rights MoveMENT (1993).

45. See H. Stephen Kaye, Disability Watch, The Status of People with DisabILITIES IN THE UNITEd STATES 26-32 (1997).

46. Some argue that there is a cultural component to disability, and that people with disabilities do have a unique and identifiable culture. See, e.g., Edward L. Hooper, Seeking the Disabled Community, reprinted in THE RAGGed EDGE (1994); Paul Longmore, The Second Phase: From Disability Rights to Disability Culture, DISABILITY RAG \& RESOURCE, Sept.-Oct. 1995, at 4, 8-9. See generally JoSEPH P. SHAPIRO, supra note 44. 
Today, most Americans see themselves as survivors of a revolution they hope is surely coming to an end. But it isn't. America's workplace revolution isn't over. It has only begun. ${ }^{47}$

Largely as a result of Title VII, the contemporary workplace, whether blue-collar, service-sector, or professional, is more diverse both racially and ethnically. Women have entered the job market in unprecedented numbers. The ADA has opened the door for people with disabilities to enter the job market. ${ }^{48}$ Class and economic disadvantage have become part of the dialogue concerning workplace fairness. ${ }^{49}$ Moreover, in the future, additional groups, such as gays and lesbians, may become protected by employment discrimination laws. ${ }^{50}$ The workplace is more diverse and less traditional, and thus, it is more complex than ever.

Not only has the composition of the workforce changed, the nature of the employer-employee relationship has changed as well. Workers entering the job market today can expect to have many different employers over the course of their working lives. In addition, many will have several different careers. The increased use of the contingent work force has made the old civil rights laws difficult to apply, as the traditional employeremployee relationship may not exist in some of these relationships. ${ }^{51}$ The trend of welfare-to-work programs is another change in the employment landscape, bringing additional "non-traditional" workers into the workplace.

47. JOSEPH H. BOYETT \& JimMIE T. BOYETT, BEyOND WORKPlace 2000: EsSENTIAL STRATEGIES FOR THE NEW AMERICAN CORPORATION xi (1995).

48. According to the Census Bureau's Survey of Income Program and Participation, the percentage of individuals with severe disabilities who are employed increased from $23.3 \%$ in 1991 to $26.1 \%$ in 1994 , representing an increase of 800,000 jobs from 2.91 million to 3.71 million. See President's Committee on Employment of People with Disabilities, Employment Rate of People with Disabilities Increases Under the Americans with Disabilities Act (visited Nov. 30, 1998) <http://www.pcepd.gov/pubs/fact/keyfacts.htm>.

49. See Richard D. Kahlenberg, The Remedy: Class, RaCe \& AfFirmative ACtion (1997).

50. See Employment Non-Discrimination Act, S. 932, H.R. 1863, 104th Cong. (1996); Senate Rejects by 50-49 Bill to Ban Job Bias Based on Sexual Orientation, Daily Lab. Rep. (BNA) No. 176 at A-9 (Sept. 11, 1996).

51. Contingent workers are generally workers who are outside of an employer's core workforce, such as those whose jobs are structured to last only a limited period of time, are sporadic, or differ in any way from the norm of full-time, long-term employment. Presently, the temporary help industry employs more than 2.3 million individuals. See EEOC Enforcement Guidance: Application of EEO Laws to Contingent Workers Placed by Temporary Employment Agencies and Other Staffing Firms, No. 915.002 (visited Nov. 30, 1998) <http://www.eeoc.gov/publicat.html>. Manpower, Inc., a Wisconsin-based temporary employment agency, is not only the world's largest temporary agency, it is the largest private employer in America. Temporary work has expanded from its "traditional" office and clerical base to include accounting, legal, engineering, medical, and computer jobs. See, e.g., id. 
These changes in the nature of jobs and the workforce have tremendous implications for civil rights law enforcement. For example, as the physical worksite is transformed, questions arise ranging from what the comparative establishment for Equal Pay Act purposes is ${ }^{52}$ to how the $\mathrm{ADA}$ can ensure equal access when there is no specific worksite. ${ }^{53}$ Moreover, as the workforce becomes more multicultural, responding to worker differences, complaints, and predicaments will become more complex. Workplace civil rights issues are no longer simply matters of black and white, or men and women; rather, they may include multiple ethnicities, languages, religions, and disabilities. Fewer families have a full-time, stay-at-home parent to take care of children and elderly parents, leaving only a working parent available to respond when family emergencies occur. Employees may be working full-time, part-time, as independent contractors, or at home. The declining influence of labor unions in many workplaces means that the traditional ways in which workers have interacted with each other and with management may no longer exist. There is a strong probability that all of these trends will continue and intensify in the workplace of the future.

At the same time, a backlash has arisen against employment civil rights. The statistical evidence of discrimination against members of protected groups has lost the power to inspire outrage and motivate change. The general public believes that systemic discrimination is not the great problem it once was. Rather, many feel that women and people of color have generally succeeded in the workplace. Thus, one sees reflected in the media and in general discourse the perception that group membership, rather than individual circumstances, has afforded unwarranted advantages to minorities and women. As a result many believe that antidiscrimination laws and affirmative action have been detrimental to individual members of majority groups and men.

Another perception is that individuals are solely responsible for their own success. If one does not succeed, the implication is that the individual is at fault, not that discrimination impeded that individual's success. For example, employers have claimed that women asked for harassment by working in a non-traditional field and by dressing and acting in a certain way or that they bring discrimination on themselves by not conforming to

52. Under Equal Pay Act analysis, the wage comparisons must be made between persons working at the same establishment. See 29 U.S.C. \$ 206(d)(1) (1994).

53. The changed character of employment has implications as well for other progressive, labor-related laws. For example, when a workforce is fragmented by distance or telecommuting, it becomes harder to organize into labor unions and engage in collective bargaining. In addition, when employees have sequential careers and different employers, their likelihood of remaining long enough with one employer in the traditional employeremployee relationship to have a pension vest for ERISA purposes is diminished. Employee Retirement Income Security Act of 1974, as amended, 29 U.S.C. \$ 1001 (1994). 
gender stereotypes. ${ }^{54}$

Managing the workplace of today requires an approach different from the traditional civil rights paradigm - in a sense, an amalgam of both methodologies. The more individualized and flexible approach, which is reflected in the disability civil rights paradigm, should be incorporated into the traditional equality model to allow employers to better respond to workplace management issues in the twenty-first century workplace. Supervising a diverse workforce by using uniform policies, which allow for little or no consideration of individual experiences or situations will not be successful. As the workforce becomes more diverse, employers need to exercise more independent judgment in crafting individualized solutions to workplace issues.

For example, the entry of participants from welfare-to-work programs into the job market demonstrates the need for the new paradigm. If welfare recipients were merely given jobs like other applicants (i.e., treated equally as in the old paradigm), experience has shown that they would not likely remain employed in great numbers. The employer must take a proactive role in responding to the particular needs of this group of potential workers. Often, this means getting involved in the questions of transportation to suburban worksites from inner cities and making available affordable childcare (even more crucial for a group in which single mothers are overrepresented). Additionally, specific job training is often not enough for former long-term welfare recipients. Training in such job basics as being punctual, following lines of command, as well as working on academic skills such as mathematics and writing, may be necessary. Employers who take these extra steps to attract former welfare recipients in a tight job market are already employing the new paradigm in the workplace.

One recently enacted federal workplace law has embraced the more flexible and individualized approach. The Family and Medical Leave Act ("FMLA") 55 requires employers to accommodate the individual needs of their employees, rather than imposing a "one size fits all" policy with respect to medical emergencies facing the family. ${ }^{56}$ As in the ADA, employers have a duty to accommodate workers pursuant to the FMLA.

The U.S. Equal Employment Opportunity Commission ("EEOC"), the government agency responsible for enforcing federal workplace

54. For example, in Price Waterhouse v. Hopkins, 490 U.S. 228, 234 (1989), a female executive was told she did not deserve a promotion because she was too aggressive and not feminine enough.

55. Family and Medical Leave Act, Pub. L. No. 103-3, 29 U.S.C. $\$ 2601$ (1993).

56. The FMLA states that every covered employee is entitled to an aggregate of twelve unpaid weeks of leave during a twelve month period for any of three reasons: 1) the birth or placement for adoption or foster care of a child; 2) the serious health condition of a spouse, child, or parent; or 3) the employee's own serious health condition. See id. $\$ 2612$. 
discrimination laws, has also begun to incorporate a more individualized approach to enforcing the law. In 1995 the EEOC embarked upon a program of alternative dispute resolution ("ADR"). ${ }^{57}$ Despite the fact that the EEOC has been grossly underfunded and understaffed for most of its existence, the Commission has begun to use formal ADR to facilitate case resolutions as the individualized approach to civil rights has finally gained broad acceptance. In each of the EEOC's twenty-three district offices, some charges of discrimination, with the consent of the parties, are diverted to mediation before being investigated. ${ }^{58}$ ADR is a flexible process which is able to be tailored to the individual dispute. It is a particularly appropriate process for resolving employment civil rights disputes as it results in "win-win" situations for employers and employees. ADR addresses the complaint while often preserving the employment relationship, leading to a more harmonious resolution and aftermath. ${ }^{59}$

In addition, the EEOC has also responded by providing more guidance on equal employment opportunity laws to its stakeholders in the form of easily accessible data, technical assistance, and information on responsibilities in the workplace. Employers, in particular, need the tools to make case-by-case determinations. They need to assess the issue of providing fairness in an increasingly complex society. To this end, such outreach to employers, employees, labor unions, and other interested members of the public is very critical to the twenty-first century workplace. $^{60}$

57. EEOC Policy Statement on Alternative Dispute Resolution Policy Statement, 2 EEOC Compl. Man. (BNA) No. N-915.002 (July 17, 1995).

58. Should mediation prove unsuccessful, the charges are then investigated. Thus, charging parties and respondents lose nothing by opting for mediation. See id.

59. It is also a "win-win" situation for the EEOC, freeing up investigators and other staff to work on more complex, systemic cases of discrimination, while reducing the inventory of pending complaints and increasing customer service. See id.

60 . The EEOC has already begun this process in a number of ways. It now operates a web site, <http://www.eeoc.gov>, which contains a range of information for employers and employees alike; it has increased its "face-to-face" outreach to employers through informal settings and through its Technical Assistance Programs ("TAPs"); and has issued a number of new policy guidances to keep all stakeholders informed of current legal developments and Commission policy. See, e.g., EEOC ADA Enforcement Guidance: Preemployment Disability-Related Questions and Medical Examinations (visited Nov. 30, 1998) $<$ http://www.eeoc.gov/publicat.html>; EEOC Enforcement Guidance on the ADA and Psychiatric Disabilities, No. 915-002 (visited Nov. 30, 1998) <http://www.eeoc.gov/ publicat.html>; EEOC Enforcement Guidance on Sex Discrimination in the Compensation of Sports Coaches in Educational Institutions, No. 915-002 (visited Nov. 30, 1998) <http://www.eeoc.gov/publicat.html>; EEOC Policy Guidance on Mandatory Binding Arbitration of Employment Discrimination Disputes as a Condition of Employment, No. 915-002 (visited Nov. 30. 1998) <http://www.eeoc.gov/publicat.html>. All current Guidance is available for downloading at the EEOC's website at <http://www.eeoc.gov/ publicat.html >. 
The disability civil rights paradigm can provide the model for an individualized, flexible, and contextual approach to civil rights enforcement. Adapting the traditional civil rights framework to a changing landscape will not be easy. Employers need to become more comfortable with the greater degree of individualized management that is now required. However, in championing greater flexibility in a new civil rights framework, we must be careful not to let the new paradigm of individualized treatment obscure the truths of the stereotypical treatment of historically discriminated groups in society. As we look for individual solutions, we must not let down our guard and fall prey to the negative stereotypes that continue to permeate our culture. Treating people as individuals, while recognizing and respecting the historical stereotypes that may have been imposed by others, is the balance that we must strike in the twenty-first century workplace. 